\title{
Jurisdictions with the Lowest Effective Tax Rates in the Post-BEPS Landscape - CbCR Evidence and Implications
}

\author{
Petr Procházka*
}

\begin{abstract}
:
The research revolves around the topic of offshore destinations and role of tax in the decision where to locate TNCs' investments or relocate employees. This paper exploits rich country-by-country reporting (CbCR) data that banking institutions operating in the EU with annual turnover over 750 million are obliged to provide publicly as of 2014 on a yearly basis. Database includes 47 banks over 5 years and 27,533 datapoints. I explore whether there is any connection between effective tax rate (ETR) and number of employees in respective subsidiaries of banking institutions. In consequent multiple regression analysis, I add more variables to the model: such as profitability, labour productivity, and other controlling variables. Conclusion is that there is no significant correlation between ETR and employee count and that TNCs tend to locate their employees on a different basis. This is a unique analysis of data that can be used by other tax avoidance researchers and policy makers.
\end{abstract}

Key words: Effective tax rate; International tax optimisation; Global mobility; Offshoring; FDI.

JEL classification: $\mathrm{H} 26 ; \mathrm{F} 38 ; \mathrm{H} 25$.

\section{Introduction}

In an increasingly interconnected and liberalised global economy, flows of production factors across borders generally tend to increase. Large TransNational Corporations (TNCs) search for the best location to tap new resources, explore new markets for their products and increase their profitability and market value as the bottom line. There is plenty of quantified evidence, such as Peter Dicken's Global Shift series (2014). TNCs may have various motives to expand internationally to new economies and their decision will depend on various determinants, such as the following list adapted from Martínez-Noya \& GarcíaCanal 2018): First, seeking markets (increasing sales) by making use of economies

Petr Procházka, University of Economics, Prague, Faculty of International Relations, Department of International Business, W. Churchill Sq. 1938/4, 13067 Prague 3 - Žižkov, Czech Republic <xprop46@vse.cz>, ORCID ID: 0000-0002-8886-6241. 
Procházka, P.: Jurisdictions with the Lowest Effective Tax Rates in the Post-BEPS Landscape CbCR Evidence and Implications.

of scale or protecting intellectual property. Second, seeking resources (increasing profitability) by tapping knowledge, specialised professionals and talent, increasing innovation and $\mathrm{R} \& \mathrm{D}$ or internalising and reducing risk, increasing control over business activity. Third, seeking cost-effectiveness by reducing agency cost, reducing labour cost or minimising tax burden (international tax optimisation).

The purpose of this paper is to provide new insights into the behaviour of transnational corporations (TNCs) in an increasingly changing environment of new tax norms and tightening cooperation in tax matters. Specifically, I will explore how the employee counts of subsidiaries or group members differ throughout different countries, be it great powers, small open economies, tax havens or not. I consider the employee count (and the count's change over years) an interesting proxy to see where trans-national corporations decide to locate their investments. Labour force is somewhat less mobile than capital and thus should reflect better the real economy changes.

As mentioned, much research on capital movement has already been done - see the literature review below. On the other hand, connection of labour mobility and taxes has been little explored. I bring an innovative approach to understand theconsequences of tax system changes on the behaviour of TNCs. Moreover, I exploit rich country-by-country data on the European bank groups that are brand new and have not been used in many cases before. Coming as a surprise, only a handful of correlations in this research are statistically significant and most of the hypotheses are rejected.

Since the beginning of the 21 st century, we have seen one important trend: service offshoring. With liberalising global trade and reducing investment barriers, service offshoring has seen a particular increase in comparison to the traditional manufacturing offshoring (Jensen 2009, Kubičková et al. 2019). Likewise, offshoring in services is more often taking place in industries with higher added value and thus focuses on specialised workers rather than simply cost reduction (which remains an important driver in any case). Shared services centres and other forms of using economies of scale take place, with 'hot spots' currently being Central \& Eastern Europe, ASEAN countries, China, India, Brazil, Mexico or Chile (EY 2013). In many cases and recently more than ever, we have seen large corporations to handle some of their tasks through outsourcing to third parties. This is done exactly with the motive of reducing fixed costs, compliance costs and externalising risks (EY 2017). Business process outsourcing (BPO) is one of the currently used methods in an increasing number of sectors - most notably accounting and tax reporting, IT, HR, recently also risk management or operations management (EY 2013). 
There is a wealth of literature considering effects of tax rate on capital mobility and choosing destination of FDI. For example, consult Dyreng \& Markle (2016); Graham, Hanlon, \& Shevlin (2011). Furthermore, Hines and Rice (1994), Dowd et al. (2017) or Janský and Palanský (2017) analyse the effects of capital investment into low-tax jurisdictions. The aforementioned evidence claims that subsidiaries in lower-tax jurisdictions (or tax havens) generally report higher profit rates as compared to employee remuneration and expected profit based on the turnover. This effect is called profit shifting. On the other hand, the biggest proportion of capital still stays in large developed economies, where it is taxed at relatively high tax levels.

The driver is often the tax level - and what really matters is the effective tax rate, as Celine Azemar (2010) argues. Thanks to their international tax planning, companies often minimise the effective tax rates and achieve values well below the statutory, or nominal, rates (Köthenbürger et al. 2018), bringing them often close to zero (Schindler 2004). Moreover, some jurisdictions tend to reduce their statutory corporate tax rates and give tax incentives to attract foreign capital, thus participating in harmful tax competition (Devereux et al. 2008). To achieve that, TNCs make use of several techniques exploiting the cross-border differences between jurisdictions, something smaller enterprises cannot afford:

- Their complex business structures allow them to move their resources between countries in which they operate. It takes a form as royalties, interest, or dividend payments sent from subsidiaries to headquarters or between the group members across borders.

- Various tax benefits or discounts provided by jurisdictions create in the case of TNCs jobs and bring capital; TNCs can negotiate with less powerful national governments as large players (Egger, Köthenbürger 2016).

When it comes to employee mobility or new hiring that accompanies capital investment, the tax impact has been little reviewed. Contrary to expectations, several sources on personal mobility show that high effective tax burden on personal income is actually not a significant reason for the move to a lower-tax jurisdiction (Thompson 2011 or Clemens 2014). Some research on the local level (Crabbé, De Bruyne 2013) suggests the opposite, which I shall take as my assumption: 
Procházka, P.: Jurisdictions with the Lowest Effective Tax Rates in the Post-BEPS Landscape CbCR Evidence and Implications.

The effective tax rate shall have a negative effect on the employees count for a subsidiary as TNCs prefer to locate their operations in the jurisdictions with a lower tax rate to save on the costs.

The statutory corporate income tax rate can be a good indicator for the decisions to be made while TNCs decide to locate their investments abroad, more so in the current highly competitive environment, where every additional advantage makes a difference and can enable market share gains against the competitors. Moreover, we have recently seen TNCs to invest in new ways of businesses in order to reduce their operation costs and tap unused resources - a prime example could be Shared Services Centres for more-skilled jobs or manufacturing facilities for less-skilled jobs (Martínez-Noya, García-Canal 2018).

In 2013, OECD expert Centre for Tax Policy and Research suggested actions that shall combat the widespread problem of the (tax) base erosion and profit shifting (BEPS). The set of 15 actions was endorsed by finance ministers of OECD and G20 members and thereafter became referred to as the OECD/G20 BEPS Action Plan (OECD 2013). In its scope and wide agreement of most of the world's economies (129 jurisdictions by May 2019) it thus constitutes an unprecedented effort in the area of international tax cooperation. The EU has always been one of the major stakeholders in it with considerable developments in BEPS Action Plan implementation (Procházka 2019).

Action 13 focuses on 'Transfer Pricing Documentation and Country-by-Country Reporting'. The concept of country-by-country reporting (CbCR) was suggested and developed by Richard Murphy in 2003 and in the report for the Tax Justice Network of 2012 Murphy promoted a wide range of data disclosures that every TNC should make (Murphy 2012). In the 2015 final report of the OECD expert group (OECD 2015), the template of country-by-country reporting for large TNCs is provided, suggesting that all TNCs with over EUR 750 million of consolidated revenue shall submit these to the national authorities, starting with the fiscal year of 2016, in compliance with the accounting standards on a yearly basis for each of the jurisdictions where they operate, namely: (1) turnover, (2) profit before tax, (3) tax, (4) number of employees, and (5) public subsidies received.

As of 9 November 2018, 75 jurisdictions (OECD 2018) adhered to the minimum standard for Action 13, excluding most notably the United States. On the other hand, the EU requires the data for TNCs with a yearly turnover over EUR 750 million and operations in at least one EU member state and transnational activities to be filed with national authorities starting from 2017 (European Parliament 2016). However, this data do not need to be made public. Nevertheless, financial institutions' groups, of which at least one entity is located in an EU member state, 
have the obligation to share their data as of 2014 under the so-called Capital Requirement Directive IV - 'CRD IV' (European Parliament 2013). I exploit this rich data on financial institutions in my research.

The purpose of my research is to analyse the differences between effective tax rates, and the research is mainly focused on legal ways to tap the differences between legal systems of varying jurisdictions. In no way I intend to analyse illicit techniques and reasoning that some TNCs use to bring additional benefits, hoping authorities will not discover their illegal financial flows and reporting that is not in line with the legal rules.

My hypothesis' claim is that the locations of new offshore centres developed in the upcoming decade will be influenced (among other motives) by international tax optimisation calculations of TNCs. In contrast to the suggestions of the previous research, I argue that the effective tax rate will have a correlation with the employee location (and the corporate mobility into these jurisdictions), The null hypothesis will state that the effective tax rate in the given jurisdiction does not have any effect on the location of employees within the given transnational corporation.

I will aim to respond to my research questions that have been structured in a logical way: Does the effective tax rate have any correlation with the employee count? Apart from the effective tax rate, which other variables could have an effect on the employee count? What jurisdictions have the lowest effective tax rate? Can we expect the employee count to increase there?

\section{Data and Methodology}

I exploit data from public country-by-country reports for the 47 largest European banks over the period 2013-2018 that were collected by a team lead by Petr Janský from Charles University of Prague and in cooperation with Data for Tax Justice published online (Janský 2018a). Petr Janský (2018b) has presented a general overview of the findings - focusing above all on the profit/employee count relationship - i.e. profit misalignment. In the latest draft from September 2019, I include the recently released 2018 data for most of the bank groups. The combined turnover of corporations included in the dataset is EUR 3,191 trillion EUR, i.e. approximately $0.8 \%$ of the world's GDP over the 6 years.

The same data, but in a limited timeframe, have been already used by Jelínková (2016 and 2018) or Oxfam (2017) with very interesting results. This is the first time (along with the overview of Janský 2018b) that the comprehensive 6-year timeline is used, moreover with the data quality assurance. The 6-year timeline allows, among other benefits, to offset the differential between the profit and tax, as some of the banks report taxes paid in the current year, which can be connected 
Procházka, P.: Jurisdictions with the Lowest Effective Tax Rates in the Post-BEPS Landscape CbCR Evidence and Implications.

to profits from the previous years. There is a group of 47 banks out of the 50 biggest and largest European entities.

Tab. 1 Descriptive statistics of the dataset (6-year aggregate).

\begin{tabular}{lllr}
\hline bank groups & 47 & profit rate (\%) & 21.29 \\
jurisdictions & 148 & labour productivity (EUR thous. / employee) & 249.516 \\
turnover (EUR bil.) & $3,191.32$ & profit per employee (EUR thous.) & 53.12 \\
profit (EUR bil.) & 679.35 & effective tax rate (\%) & 25.29 \\
tax (EUR bil.) & 171.82 & & \\
employees (mil.) & 12.790 & & \\
\hline
\end{tabular}

Source: Data collected by Janský (2018a) + authorial computation.

Atwood et al. (2012) used simple descriptive statistics to measure the difference between the statutory tax rate and the effective tax rate to analyse the geographical patterns. Markle and Shackelford (2012) used the Orbis database with the same variables but less reliable data. They analyse the sums of turnover, profit and tax paid by the aggregate of corporations to analyse also the geographical differences. Likewise, I will analyse the effective tax rates among individual jurisdictions to point out the differences.

Apart from simple descriptive statistics comparing the effective tax rates among jurisdictions, I seek to verify the impact of a tax rate on the employee count to see what causes the selection of their operations locations by TNCs (the bank sector in this case).

- simple correlation: the employee count explained by the effective tax rate, relationships among other variables

- multiple linear regression: the employee count explained by the effective tax rate (adding profit/turnover rate and other variables)

- descriptive statistics (the effective tax rate)

- clustering of jurisdictions

\section{Results}

After applying statistical methods to my structured dataset, I can analyse the effect of selected variables on my dataset. Firstly, I check the impact of the employee count by a multiple regression model. Secondly, by a simple correlation, I investigate the relationship between all the variables in my model. Thirdly, by pure descriptive statistics, I identify jurisdictions with the lowest effective tax 
rates. In the latter part of results section of my paper, we come to classifying the jurisdictions into clusters.

Tab. 2 Multiple linear regression (basic model), on the employees number by jurisdiction

\begin{tabular}{llllll}
\hline Model & B & Std. Error & $\boldsymbol{\beta}$ & $\mathbf{t}$ & Sig. \\
\hline Constant) & 2773.323 & 134.833 & & 20.569 & 0.000 \\
Tax Rate & 351.985 & 143.362 & 0.038 & 2.455 & 0.014 \\
Profit Rate & 4.780 & 11.001 & 0.007 & 0.434 & 0.664 \\
Labour Productivity & -46.680 & 31.890 & -0.023 & -1.464 & 0.143 \\
\hline
\end{tabular}

Source: Data collected by Janský (2018a) + authorial computation.

Note: Dependent variable: Employees.

\section{RQ1:}

Does the effective tax rate have any correlation with the employee count? Does the effective tax rate have any correlation with the employee count, controlling for the profit/turnover rate and other variables?

Yes, it does. The effect (noted in Table 2) is nonetheless positive, despite the expectations - both for simple correlation (see below in Table 4) and for multiple linear regression while accounting for other variables. There is a statistically significant positive correlation between the number of employees and the effective tax rate. In other words, there are more employees in banks' entities of the countries with high tax rate. Profit/turnover rate and labour productivity (turnover/employee) have not proven to have a statistically significant impact in this model.

If I remove the extreme top and bottom 5\% of observations and add total turnover and total profit to control for other impacts, I arrive at slightly different conclusions. The effective tax rate remains a statistically significant correlate of the employee number (positively) and labour productivity is a new statistically significant correlate (negatively), i.e. countries where entities have a larger workforce headcount also tend to have a lower proportion of the turnover per employee. I note the results in the following Table 3 . This could go in hand with the amount of added value between various levels of the supply chain - activities with lower added value like customer service, invoicing or data processing involve more physical work, on the other hand specialised tasks like marketing, legal 
Procházka, P.: Jurisdictions with the Lowest Effective Tax Rates in the Post-BEPS Landscape CbCR Evidence and Implications.

services, consulting or management do need individual people to make decisions with high added value.

Tab. 3 Multiple linear regression (adjusted model) on the employees number by jurisdiction

\begin{tabular}{llllll}
\hline Model & B & Std. Error & $\boldsymbol{\beta}$ & $\mathbf{t}$ & Sig. \\
\hline Constant) & 462.245 & 59.635 & & 7.751 & 0.000 \\
Turnover & 3.418 & 0.031 & 0.916 & 110.151 & 0.000 \\
Profit before tax & -0.205 & 0.103 & -0.017 & -1.995 & 0.046 \\
Tax Rate & 130.078 & 60.780 & 0.014 & 2.140 & 0.032 \\
Profit Rate & 2.439 & 4.740 & 0.003 & 0.514 & 0.607 \\
Profit per employee & 41.129 & 30.829 & 0.01 & 1.343 & 0.179 \\
\hline Labour Productivity & -105.191 & 17.946 & -0.051 & -5.862 & 0.000 \\
\hline Source: Data collected
\end{tabular}

Source: Data collected by Janský (2018a) + authorial computation.

Note: Dependent variable: Employees.

\section{RQ2:}

Apart from the effective tax rate, which other variables could have an effect on the employee count?

When analysing the relationships among all the variables respectively, I find some interesting correlations. Specifically these relate to the employees count, effective tax rate, profit rate, labour productivity and profit per employee. I provide the description of the relationships below; results are presented in Table 4. 
Tab. 4 Correlation matrix between the variables (Pearson coefficient)

\begin{tabular}{|c|c|c|c|c|c|c|c|}
\hline Variable & Employees & $\begin{array}{l}\text { Tax } \\
\text { Rate }\end{array}$ & $\begin{array}{l}\text { Profit } \\
\text { Rate }\end{array}$ & $\begin{array}{l}\text { Labour } \\
\text { Productivity }\end{array}$ & $\begin{array}{l}\text { Profit per } \\
\text { employee }\end{array}$ & Turnover & $\begin{array}{c}\text { Profit } \\
\text { before } \\
\text { tax }\end{array}$ \\
\hline Employees & $1-000$ & $0-041 * *$ & $0-007$ & $-0-021$ & $-0-020$ & $0-904 * *$ & $0-546 * *$ \\
\hline Tax Rate & $0-041 * *$ & $1-000$ & $0-006$ & $-0-006$ & $0-000$ & $0-032 *$ & $0-015$ \\
\hline Profit Rate & $0-007$ & $0-006$ & $1-000$ & $0-003$ & $0-138 * *$ & $0-002$ & $0-029 *$ \\
\hline $\begin{array}{l}\text { Labour } \\
\text { Productivity }\end{array}$ & $-0-021$ & $-0-006$ & $0-003$ & $1-000$ & $0-650^{* *}$ & $0-024$ & $0-025$ \\
\hline $\begin{array}{l}\text { Profit per } \\
\text { employee }\end{array}$ & $-0-020$ & $0-000$ & $0-138 * *$ & $0-650 * *$ & $1-000$ & $0-001$ & $0-060 * *$ \\
\hline Turnover & $0-904 * *$ & $0-032 *$ & $0-002$ & $0-024$ & $0-001$ & $1-000$ & $0-618 * *$ \\
\hline $\begin{array}{l}\text { Profit } \\
\text { before tax }\end{array}$ & $0-546^{* *}$ & $0-015$ & $0-029 *$ & $0-025$ & $0-060 * *$ & $0-618^{* *}$ & $1-000$ \\
\hline
\end{tabular}

Source: Data collected by Janský (2018a) + authorial computation.

Note: ** correlation is significant at the 0.01 level, * correlation is significant at the 0.05 level.

Firstly, profit rate of the subsidiary, labour productivity or profit per employee do not have a significant correlation with the number of employees. Secondly, as reflected in the previous results already, countries where subsidiaries tend to have more employees and higher turnover have also higher effective tax rates. Searching for some previous evidence, it turns out to be in line with the basic presumption that large economies generally tax the corporations more, as the elasticity is lower - in other words, big markets are still interesting for corporations even with high tax rates (Exbrayat, Geys 2014). One important point is that there is a higher profit rate in lower tax jurisdictions - which is not statistically significant when it comes to the labour productivity and the profit per employee ratio. An interesting relationship is found regarding the profit rate. As expected, subsidiaries with higher profit/turnover ratio also report higher labour productivity and higher profit per employee amount. 
Procházka, P.: Jurisdictions with the Lowest Effective Tax Rates in the Post-BEPS Landscape CbCR Evidence and Implications.

RQ2:

What jurisdictions have the lowest effective tax rate? Can we expect the employee count to increase there?

In general, we observe that there are some jurisdictions with low effective tax rates that are not regarded neither listed as tax havens. On the other hand, there are traditional low-tax jurisdictions that do not appear either. It might be due to the evolution throughout time, specific nature of the banking industry and its regulations, or due to the local and national incentives for investment. Table 5 below shows the lowest effective tax rate jurisdictions in the banking sector, excluding extreme values with a very small turnover (below EUR 100 million for the period 2013-2018). It includes jurisdictions with the effective tax rate below $10 \%$. As we can see, there are in total 5 jurisdictions which had zero or negative tax. I have to note that in some cases, there is a discrepancy between the real tax charged, tax paid within the observed period and the tax that was deferred from/to other years.

According to my results that I reflected in the Table 5, the lowest effective tax rates do not imply higher employee productivity, higher profitability per employee or higher employee numbers, but they do imply higher profit/turnover ratio (profit rate). Thus, I could argue what many researchers before have confirmed - that tax is a driver for capital mobility and investments. Thanks to my paper it looks like it applies less to the employee location and mobility. The highest correlation for employee counts is with the total turnover, i.e. employees get contracted where sales or operations take place. It can also be a powerful indicator to prove that the profit shifting to low-tax or low-transparency havens is on a decrease. 
European Financial and Accounting Journal, 2020, vol.15, no. 1, pp. 33-52.

Tab. 5 Jurisdictions with the lowest effective tax rate (ETR)

\begin{tabular}{|c|c|c|c|c|}
\hline Country & $\begin{array}{l}\text { Turnover } \\
\text { (EUR mil.) }\end{array}$ & $\begin{array}{l}\text { Profit before tax } \\
\text { (EUR mil.) }\end{array}$ & $\begin{array}{l}\text { Tax } \\
\text { (EUR mil.) }\end{array}$ & $\begin{array}{r}\text { Tax rate }(\text { ETR }) \\
(\%)\end{array}$ \\
\hline Bahamas & 282 & 133 & 0 & 0.00 \\
\hline Bahrain & 1,244 & 197 & 0 & 0.00 \\
\hline Bermuda & 1,499 & 680 & 0 & 0.00 \\
\hline Cayman Islands & -200 & 303 & -8 & 0.00 \\
\hline Mozambique & 155 & 29 & 0 & 0.00 \\
\hline Saudi Arabia & 739 & 2490 & 33 & 1.33 \\
\hline Kuwait & 233 & 101 & 3 & 2.97 \\
\hline Nigeria & 922 & 490 & 21 & 4.29 \\
\hline Vanuatu & 5,325 & 478 & 23 & 4.81 \\
\hline Ireland & 31,509 & 15,207 & 780 & 5.13 \\
\hline Mauritius & 2,046 & 1,413 & 73 & 5.17 \\
\hline Jersey & 5,261 & 2,815 & 157 & 5.58 \\
\hline Channel Islands & 2,074 & 1,179 & 80 & 6.79 \\
\hline China, P.R.: Mainland & 23,704 & 15,035 & 1,047 & 6.96 \\
\hline Isle of Man & 2,207 & 1,187 & 88 & 7.41 \\
\hline Serbia & 4,340 & 1,441 & 124 & 8.61 \\
\hline Lebanon & 162 & 166 & 15 & 9.00 \\
\hline Qatar & 1,100 & 487 & 44 & 9.03 \\
\hline Guernsey & 1,388 & 692 & 66 & 9.54 \\
\hline Bulgaria & 5,111 & 1,891 & 182 & 9.62 \\
\hline
\end{tabular}

Source: Data collected by Janský (2018a) + authorial computation. 
Procházka, P.: Jurisdictions with the Lowest Effective Tax Rates in the Post-BEPS Landscape CbCR Evidence and Implications.

\section{Classification of countries}

Looking at the relationship of turnover and the effective tax rate, I can describe several groups of jurisdictions. There are big players with over EUR 100 billion of turnover in our dataset over the 6 years, having generally slightly higher tax rates than average. Especially Spain has a very high reported effective tax rate, probably due to the post-crisis consolidation and potentially also reporting differences. There are low-tax jurisdictions with low amounts of turnover (described in the table above). From the high-tax jurisdictions with a notable turnover, apart from Spain (105\% ETR) I should point out Puerto Rico (86\%), Italy $(59 \%)$ or Hungary $(55 \%)$. An interesting case is the one of Switzerland, where the European banks report a relatively low amount of turnover (EUR 15 billion over 6 years) and the total profit is negative (EUR -2.4 billion). Some of the groups do not even report data for Switzerland despite the fact the EU obliges them to do so. It needs to be noted that the tax reported by bank groups does not always coincide with the year when the particular profit was generated. Most of this adjustment should be offset thanks to the fact that I am using a 6-year span. However, some irregularities shall still occur.

Fig. 1 Classification of jurisdictions: relationship between ETR and turnover

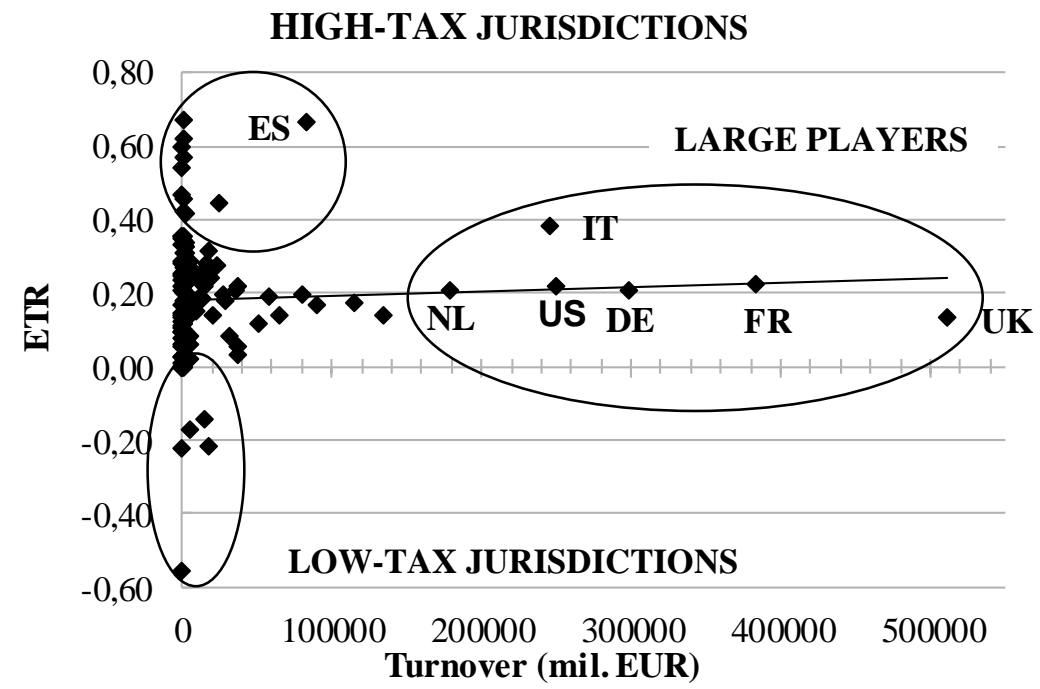

Source: Data collected by Janský (2018a) + authorial computation.

\section{Discussion with other research}

When I compare my results of the effective tax rate with the statutory tax rate as indicated by national laws, we arrive at striking differences. 
These are on the both sides, i.e. the statutory tax rate being considerably higher or considerably lower that the effective tax rate. The principal reason would be international tax optimisation, use of various tax policies and applying tax treaties on the profit. This can be in a big part the reason behind large percentage differences for small volumes of the turnover. Another explanation could be that there are different methodologies among banking groups on how to declare their taxes. The methodologies can be viewed at the site where data was published. The later source of the reason behind data discrepancy might be the difference between the years when profits are reported and when the taxes are paid. In recent past, the statutory tax rates were falling considerably and the effective tax rates were falling as well - however, at a slower pace. This could imply two things: first, that there is a tax competition going on among jurisdictions in order to attract the highly mobile capital; second, that the transparency increase and tax avoidance and evasion are on a decrease, therefore the effective tax rates are falling slower (Hines et al. 2010, page 932). Figure 7 below provides a comparison of the effective tax rates by jurisdictions as compared to their statutory tax rates (KPMG 2018). The same methodology has been used in the research of Dowd et al. (2017) on the data from U.S. corporations with similar results.

\section{Fig. 2 Tax difference by jurisdiction (effective tax rate - statutory tax rate)}

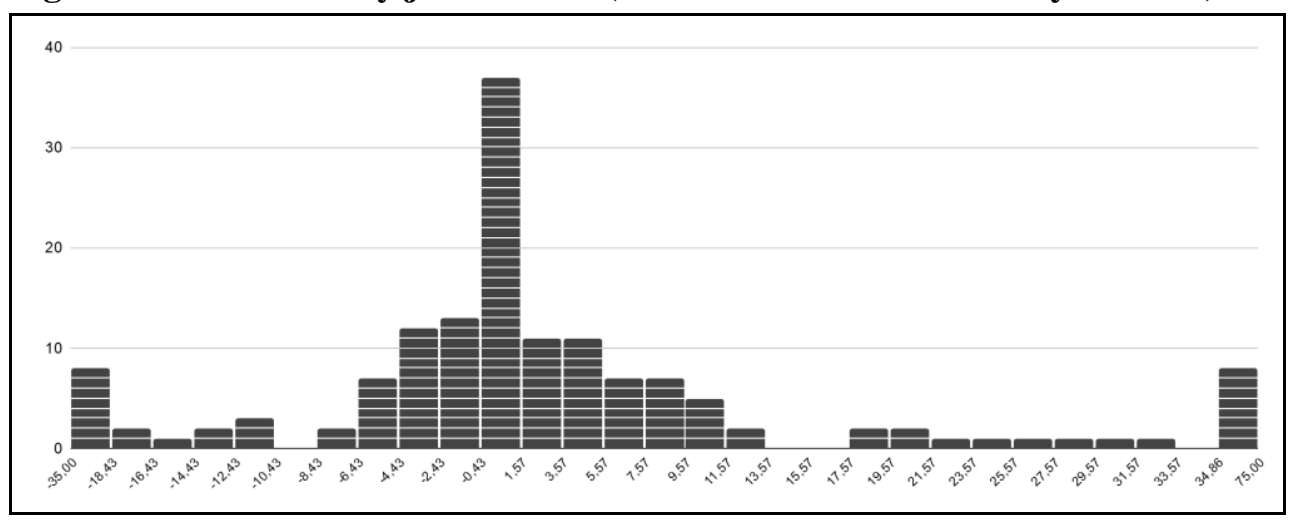

Source: Data collected by Janský (2018a) + authorial computation.

The global average effective tax rate of our dataset is slightly higher than previous research from various sources, varying between $20 \%$ and $25 \%$ - as reviewed by PwC (PwC 2016). Devereux et al. (2008) proved that government subsidies, grants and tax levels have only a secondary effect on firm plant locations, with largest importance being clustering of industry producers and suppliers in the location (Devereux et al. 2007). My research suggests similar results. When I compare the research outcomes to the 'hot spots' listed by aforementioned Ernst\&Young overview (EY 2013) for shared services centres, I have not confirmed any specific results in the banking sector. The reason could be there 
Procházka, P.: Jurisdictions with the Lowest Effective Tax Rates in the Post-BEPS Landscape CbCR Evidence and Implications.

is still a higher proportion of employees in the core tasks that cannot be relocated to other, lower-jurisdiction countries - such as a direct client. However, I dare to argue that business process outsourcing and offshoring of tasks will further expand with the increase of interconnectedness and improvements in the communication technology. The effective tax rate is just apparently not the main driver for the investment location.

\section{Conclusions}

I have proved that there is a higher profit/turnover ratio in jurisdictions with lower effective tax rates. I have not proved that there would be a higher number of employees in lower tax jurisdictions, or that the labour productivity and/or profit per employee would be higher there. It could be explained by the fact that TNCs rather aim to relocate their employees to jurisdictions with significantly higher labour productivity and tax burden is only a secondary, relatively unimportant point. However, tax remains an important issue to be tackled by relocation and mobility specialists and has its considerable share within the labour costs that a TNC has to cover.

When it comes to clustering the jurisdictions, I can clearly see the group of "small tax havens". Looking at these, the variables seem to report lower values of effective tax rates than the rest of data. Simply put, it does not pay off to relocate employees to jurisdictions with lower effective tax rates, as shown by some previous research - agglomeration effects with higher labour productivity can outweigh the benefits from low tax jurisdictions that do not provide many other benefits (Brülhart et al. 2012). Yet, it could be profitable to locate investments there- which is already happening in most cases as confirmed by Janský (2018).

To name the limitations of my research, firstly, I analyse only the banking sector and all its specificities need to be taken into account. Banking sector has different criteria than production TNCs for locating their operations. Secondly, I take into account just the corporate tax rate. I exclude other indirect and direct taxes, such as employee income tax, VAT, or social security payments, or any type of withholding tax, e.g. the UK banking levy. Also, the Netherlands has different rules set for capital gains originating abroad or domestically. I also exclude the effect of other non-taxation barriers as it is not the goal of this analysis. However, the legal rules and restrictions for investment, operations and production need to be taken into account as they can generate additional costs of compliance. For example, a low tax rate does not mean that a TNC can start its operations in the given jurisdiction easily. There could be labour market restrictions, etc. (Griffith, Macartney 2014). I exclude the potential of some markets while deciding for the investment destination. In the end, it is the ultimate profitability / ROI that 
drives the decision of the TNCs to determine the location of their investment, long-term or short-term depending on the company's strategy. Tax is only one of the components which list (not limited to): PESTE analysis, market size, estimated sales and profitability, $R \& D$ potential or prestige.

This overview can be used as a guide to TNCs wishing to locate their investments internationally. It also serves the global tax authorities like OECD/G20 expert groups to see the persisting tax differences landscape. I definitely promote globally effective solutions and lowering barriers to investment (Griffith, Miller 2014), a reduction of harmful tax competition among jurisdiction, as this has proven to reduce the global economy effectiveness (Azemar, Delios 2008). I am also keen to achieve a higher mobility and investment into R\&D, as opposed to protectionism (Abramovsky et al. 2017 or Akcigit et al. 2018). Previously cited research (Exbrayat, Geys 2014) has proven that increasing international trade and higher interconnectedness lower the benefits and possibilities of jurisdictions to set taxes differently from the global average.

There has been some research (recently Bastani, Waldenström 2018, Saez, Stancheva 2018 and Jacobs, Rusu 2018) arguing that a globally efficient solution is to bring the capital income tax to zero and that it is more effective to tax workers or consumption itself through indirect taxes. Other authors claim this statement may not be valid (Baiardi et al. 2017). One interesting piece of research on the Norwegian municipalities found the reverse causation: higher mobility of firms was causing pressure on municipalities which consequently lowered their taxes (Carles et al. 2005). Such correlation was indeed confirmed on the global level as well (Hines et al. 2010) - yet the cause is not that certain. Nonetheless, in the current world system which is still a global arena of various players with no single ultimate authority (Procházka 2015), the TNCs will strive to maximize their profits and jurisdictions will aim to attract investment to improve the position of their economies in the global value chain and gain wealth. At the same time, jurisdictions in general will hardly abandon the corporate tax as in most of the cases it is an important source of income. Thus, it is still important to analyse the differences between jurisdictions to improve transparency, predictability and to help find the best-practice solutions.

Thanks to this research we have seen that within the next decade of 2020s, some previously attractive jurisdictions with low effective tax rates are likely to lose their importance as the BEPS process dismisses regimes of low transparency and hybrid mismatches. On the other hand, some jurisdictions (Bahamas, Bermuda, Channel Islands, Isle of Man, Ireland) will retain low effective tax rates and others, like all the Gulf Cooperation Council Countries, Nigeria, Uganda or China and Singapore seem to get their rates reduced recently and thus shall be on the radar for potential investors (in this case the banking industry). 
Procházka, P.: Jurisdictions with the Lowest Effective Tax Rates in the Post-BEPS Landscape CbCR Evidence and Implications.

In the European continent, Serbia, Montenegro and Bosnia and Herzegovina report interestingly low rates.

As pointed out in the introduction, low effective tax rate is not the only or the single most important criterion for TNCs to locate their investments, but it is becoming increasingly important as the competition becomes fiercer globally. For future research, I would recommend: (1) analysing further CbCR data on banks in the upcoming years, (2) analysing CbCR data on all large TNCs, as soon as they become publicly available and (3) analysing particular cases to understand motives behind the quantified numbers.

\section{References}

Abramovsky, L., Griffith, R., Miller, H., 2017. Domestic effects of offshoring high skilled jobs: complementarities in knowledge production. Review of International Economics, 25(1), February 2017, pp 1-20.

Akcigit, U., Grigsby, R. J., Nicholas, T., Stantcheva, S., 2018. Working Paper. NBER Working Paper 24982. Available from: <scholar.harvard. edu/stantcheva/publications/taxation-and-innovation-20th-century>. [15 January 2019].

Atwood, T. J., Drake, M. S., Myers, J. N., Myers, L. A., 2012. Home country tax system characteristics and corporate tax avoidance: International evidence. The Accounting Review, 87(6), 1831-1860.

Azemar, C., Delios, A., 2008. Tax competition and FDI: the special case of developing countries. Journal of the Japanese and International Economies, 22(1), pp. 85-108.

Azemar, C., 2010. International corporate taxation and U.S. multinationals' behaviour: an integrated approach. Canadian Journal of Economics $=$ Revue canadienne d'économique, 43(1), pp. 232-253.

Baiardi, D., Profeta, P., Puglisi, R., Scabrosetti, S., 2017. Tax Policy and Economic Growth: Does It Really Matter? CESifo Working Paper Series No. 6343. Available from: <ssrn.com/abstract=2932798>. [15 February 2019].

Bastani, Spencer, Waldenström, Daniel, 2018. How should capital be taxed? Theory and evidence from Sweden, CEPR Discussion Paper No. DP12880. Available from: 〈ssrn.com/abstract=3167245>. [25 January 2019].

Brülhart, M., Jametti, M., Schmidheiny, K., 2012. Do agglomeration economies reduce the sensitivity of firm location to tax differentials? The Economic Journal, 122(563), 1069-1093.

Clemens, M. A., 2014. A Case against Taxes and Quotas on High-Skill Emigration. CGD Working Paper 363. Washington, DC: Center for Global 
Development. Available from: <cgdev.org/sites/default/files/clemens\%20case \%20against\%20taxes\%20web.pdf>. [15 March 2019].

Crabbé, K., De Bruyne, K., 2013. Taxes, agglomeration rents and location decisions of firms. De Economist, 161(4), 421-446.

Devereux, M., Griffith, R., Simpson, 2007. Firm location decisions, regional grants and agglomeration externalities. Journal of Public Economics, 91, 413-435, April 2007.

Devereux, M., Lockwood, B., Redoano, M., 2008. Do countries compete over corporate tax rates? Journal of Public Economics, 92(5-6), 1210-1235.

Dicken, P., 2014. Global Shift. 7th edition. London: Sage Publications.

Dowd, T., Landefeld, P., Moore, A., 2017. Profit shifting of U.S. multinationals, Journal of Public Economics, 148, issue C, p. 1-13.

Dyreng, S. D., Markle, K., 2016. The effect of financial constraints on taxmotivated income shifting by U.S. multinationals. The Accounting Review, 91(6), 1601-1627.

Egger, P., Köthenbürger, M., 2016. Hosting multinationals: Economic and fiscal implications. Aussenwirtschaft, , vol. 67(01), pp. 45-69, February. University of St. Gallen, School of Economics and Political Science, Swiss Institute for International Economics and Applied Economics Research. Available from: <ideas.repec.org/a/usg/auswrt/2016670145-69.html>. [12 January 2019].

European Parliament, 2013. Directive 2013/36/EU of the European Parliament and of the Council of 26 June 2013 on access to the activity of credit institutions and the prudential supervision of credit institutions and investment firms, amending Directive 2002/87/EC and repealing Directives 2006/48/EC and 2006/49/EC Text with EEA relevance.

European Parliament, 2016. Council Directive (EU) 2016/881 of 25 May 2016 amending Directive 2011/16/EU as regards mandatory automatic exchange of information in the field of taxation.

Exbrayat, N., Geys, B., 2014. Trade integration and corporate income tax differentials. International Tax and Public Finance, 21(2), 298-323.

EY, 2013. Worldwide tax reporting in the shared services age: seizing the opportunity and managing the risk. Presentation. Available from: <ey.com/Publication/vwLUAssets/Worldwide_tax_reporting_-_Chicago/\$FILE/ Worldwide_tax_reporting.pdf >. [10 December 2018].

EY, 2017. Handling tax in a shared services environment. Available from: $<$ ey.com/Publication/vwLUAssets/ey-2017-handling-tax-in-a-shared-servicecenter-environment/\%24FILE/ey-2017-handling-tax-in-a-shared-service-centerenvironment.pdf>. [1 December 2018]. 
Procházka, P.: Jurisdictions with the Lowest Effective Tax Rates in the Post-BEPS Landscape CbCR Evidence and Implications.

Griffith, R., Macartney, G., 2014. Employment Protection Legislation, Multinational Firms and Innovation. Review of Economics and Statistics, 96(1), 135-150.

Griffith, R., Miller, H., 2014. Taxable Corporate profits. Fiscal Studies, vol. 35, no. 4, pp. 535-557 (2014) 0143-5671.

Hines, J. R., Jr., Griffith, R., Sørensen, P. B., 2010. International Capital Taxation. In: Dimensions of Tax Design: The Mirrlees Review, edited by T. J. Besley et al., 914-96. Oxford: Oxford University Press, 2010.

Hines, J., Rice, E. M., 1994. Fiscal Paradise: Foreign Tax Havens and American Business. The Quarterly Journal of Economics, 109, issue 1, pp. 149-182.

Jacobs, B., Rusu, A., 2018. Why is the Long-Run Tax on Capital Income Zero? Explaining the Chamley-Judd Result., Mimeo: Erasmus University Rotterdam.

Janský, P., Palanský, M., 2017. Estimating the Scale of Profit Shifting and Tax Revenue Losses Related to Foreign Direct Investment. IES Working Paper 25/2017. IES FSV. Charles University.

Janský, P., 2018a. EU banks' country-by-country reporting data (2013 - 2017). Dataset. Available from: <datahub.io/StephenAbbott/eu_banks_country_by_ country_reporting>. [15 December 2018].

Janský, P., 2018b. European Banks and Tax Havens: Evidence from Country-byCountry Reporting. IES Working Papers forthcoming/2018. IES FSV. Charles University of Prague.

Jelínková, E., 2016. Estimating the Misalignment between the Locations of Profits and Economic Activities of EU's Banks. Bachelor Thesis. Charles University of Prague.

Jelínková, E., 2018. The Role of Tax Havens for Banks: Evidence from Two Firm-Level Datasets. Diploma Thesis. Charles University of Prague.

Jensen, P., 2009. A learning perspective on the offshoring of advance service. Journal of International Management, 15, pp. 181-193.

Köthenbürger, M., Mardan, M., Stimmelmayr, M., 2018. Profit Shifting and Investment Effects: The Implications of Zero-Taxable Profits. CESifo Working Paper Series 6895, CESifo Group Munich. Available from: <cesifo.org/en/publikationen/2018/working-paper/profit-shifting-and-investmenteffects-implications-zero-taxable>. [22 December 2018].

KPMG, 2018. Corporate tax rates table. Available from: $<$ home.kpmg/xx/en/home/services/tax/tax-tools-and-resources/tax-rates-online/ corporate-tax-rates-table.html>. [22 December 2018].

Kubičková, V., Čukanová, M., Kovačevič, D., 2019. Demand for Business Services in the Visegrad Group Countries and It's Factors of Development. Focus 
On Slovakia. Proceedings of 19th International Joint Conference Central and Eastern Europe in the Changing Business Environment. Prague 2019.

Markle, K. S., Shackelford, D. A., 2012. Cross-country comparisons of corporate income taxes. National Tax Journal, 65(3), 493-527,487-488.

Martínez-Noya, A., García-Canal, E., 2018. Location, shared suppliers and the innovation performance of $\mathrm{R} \& \mathrm{D}$ outsourcing agreements. Industry \& Innovation 25:3, pp. 308-332.

Murphy, R., 2012. Country-by-Country Reporting - Accounting for globalisation locally. Tax Justice Network. Available from: <taxresearch.org.uk/Documents /CBC2012.pdf>. [15th January 2019].

OECD, 2013. Action plan on base erosion and profit shifting. OECD Publishing pp. 1-44. Available from: <oecd.org/tax/action-plan-on-base-erosion-and-profitshifting-9789264202719-en.htm>. [1 January 2019].

OECD, 2015. Transfer Pricing Documentation and Country-by-Country Reporting, Action 13 - 2015 Final Report. OECD/G20 Base Erosion and Profit Shifting Project. OECD Publishing, Paris.

OECD, 2018. Signatories of the Multilateral Competent Authority Agreement on the Exchange of Country-by-Country Reports. Last updated 9 November 2018. Available from: <oecd.org/tax/beps/CbC-MCAA-Signatories.pdf>. [11 January 2019].

Oxfam, 2017. Opening the vaults: the use of tax havens by Europe's biggest banks. Briefing Paper. Available from: <policy-practice.oxfam.org.uk /publications/opening-the-vaults-the-use-of-tax-havens-by-europes-biggest-banks620234>. [20 December 2018].

Procházka, P., 2015. Globalisation processes and international organisations evolution: Effectivity and reform of international organisations with an example of the WTO. Diploma thesis. University of Economics, Prague.

Procházka, P., 2019. BEPS (Base Erosion and Profit Shifting) Action Plan Initiated by OECD/G20: Implementation Status in Czechia and Other CEE Countries. Proceedings of 19th International Joint Conference Central and Eastern Europe in the Changing Business Environment. Prague 2019.

PwC, 2016. International Comparison of Effective Corporate Tax Rates. Prepared for Alliance for Competitive Taxation. Available from: <actontaxreform.com/wpcontent/uploads/2016/09/International-Comparison-of-Effective-Corporate-TaxRates_FINAL_20160926.pdf>. [1st January 2019].

Saez, E., Stantcheva, S., 2018. A Simpler Theory of Optimal Capital Taxation. Journal of Public Economics [also: NBER Working Paper 22664] 162: 120-142. 
Procházka, P.: Jurisdictions with the Lowest Effective Tax Rates in the Post-BEPS Landscape CbCR Evidence and Implications.

Thompson, J., 2011. The impact of taxes on migration in New England. Political Economy Research Institute, University of Massachusetts. Available from: <peri.umass.edu/fileadmin/pdf/published_study/Migration_PERI_April13.pdf>. [18 December 2018]. 